\title{
Mapping the New Empire: A Geographical Look at the Fourth Century
}

\author{
Giusto Traina
}

Despite the scant evidence for the creation of both a practical and a mental map of the imperial world, geography seems to have been a matter of some concern in Late Roman civilization: the 'democratization of culture' and the progress of information systems seems to have produced a deeper sensitivity for geography. ${ }^{2}$ Geographical texts and maps were a part of education, as is demonstrated by Eumenius' famous speech in support of the restoration of the school of the Maenianae in Autun (297/298). ${ }^{3}$ Closing his speech, Eumenius evokes the representations of "separate regions":

1 This paper is a sort of prequel of Giusto Traina, "Mapping the World under Theodosius II," in Theodosius II. Rethinking the Roman Empire in Late Antiquity, ed. Christopher Kelly (Cambridge, Eng., 2013), pp. 115-171. In some points, I reconsider what I have already expressed, but in a less systematic form, in Giusto Traina, "Geografia dell'impero," in Enciclopedia costantiniana. Sulla figura e l'immagine dell'imperatore del cosiddetto Editto di Milano. 313-2013, eds. Alberto Melloni, Mara Dissegna and Davide Dainese, 1 (Rome, 2013), pp. 583-598. Lavish thanks to Francesca Gazzano, Mark Humphries and Hervé Inglebert for their suggestions.

2 See Jean-Michel Carrié, "Antiquité tardive et 'démocratisation de la culture'. Un paradigme à géométrie variable," Antiquité tardive 9 (2001), 27-46; Averil Cameron, "Democratization Revisited: Culture and Late Antique and Early Byzantine Elites," in The Byzantine and Early Islamic Near East. Elites Old and New, eds. John Haldon, Lawrence I. Conrad, Studies in Late Antiquity and Early Islam 1.vi (Princeton, 2004), pp. 91-108. I suggest a "democratization of landscape” in Giusto Traina, "Paesaggio e 'decadenza'. La palude nella trasformazione del mondo antico," in Società romana e impero tardoantico, 3: le merci gli insediamenti, ed. Andrea Giardina (Rome-Bari, 1986), pp. 711-730; 905-917 ; Id., "Luoghi della transizione. Appunti sul paesaggio antico," Compar(a)ison 2 (1998), 79-91. For a general survey see Mark Humphries, "A New Created World: classical geographical texts and Christian contexts in late antiquity," in Texts and Culture in Late Antiquity: inheritance, authority, and change, ed. J.H. David Scourfield (Swansea, 2007), pp. 33-67.

3 See Eumenius, Paneg. Lat. 9 (5) 20.2-3. Giuseppe La Bua, "Patronage and education in thirdcentury Gaul: Eumenius' Panegyric for the Restoration of the Schools," Journal of Late Antiquity 3 (2010), 300-315; Antony Hostein, La cité et l'Empereur. Les Éduens dans l'Empire romain d'après les Panégyriques latins (Paris, 2012), pp.177-250; Traina, "Mapping the World", pp. $155^{-158 .}$

(C) GIUSTO TRAINA, 2015 | DOI 10.1163/9789004291935_005

This is an open access chapter distributed under the terms of the Creative Commons AttributionNoncommercial 3.o Unported (CC-BY-NC 3.0) License. 
Here let the most noblest accomplishments of the bravest Emperors be recalled through representations of the separate regions (per diuersa regionum argumenta), while the twin rivers of Persia and the thirsty fields of Libya and the recurved horns of the Rhine and the many-cleft mouth of the Nile are seen again as eager messengers constantly arrive. Meanwhile the minds of the people gazing upon each of these places will imagine Egypt, its madness given over, peacefully subject to your clemency, Diocletian Augustus, or you, invincible Maximian, hurling lightning upon the smitten hordes of the Moors, or beneath your light hand, lord Constantius, Batavia and Britannia raising up their muddied heads from woods and waves (squalidum caput siluis et fluctibus exserentem), or you, Maximian Caesar, trampling upon Persian bows and quivers. For now, at last it is a delight to see a picture of the world, since we see nothing in it which is not ours. ${ }^{4}$

The personifications of Britannia and Batavia, theaters of Constantius Chlorus' campaigns, recall the topos of the barbarians living in marginal lands like woodlands and marshlands. ${ }^{5}$ This image, recalling the "anxiety" of late antique society, is not unusual in the literature of the period. For example, the anonymous panegyrist of 307 praises Maximianus for having "overwhelmed, forced to capitulate and resettled the fiercest tribes of Mauretania (the rebels known as Quinquegentani), who had trusted to their inaccessible mountaintops and natural fortifications", when at the same time "young" Constantine traverses the limites tirelessly, where the Roman Empire presses upon barbarian peoples. ${ }^{6}$

4 Eumenius, Paneg. Lat. 9 (5) 21.1-3, trans. C.E.V. (Ted) Nixon and Barbara S. Rodgers (Berkeley, 1994): "ibi fortissimorum imperatorum pulcherrimae res gestae per diversa regionum argumenta recolantur, dum calentibus semperque venientibus victoriarum nuntiis, revisuntur gemina Persidos flumina et Libyae arva sitientia, et convexa Rheni cornua et Nili ora multifida, dumque sibi ad haec singula intuentium animus adfingit, aut sub tua, Diocletiane Auguste, dementia, Aegyptum, furore posito, quiescentem, aut te Maximiane invicte, perculsa Maurorum agmina fulminantem aut sub dextera tua, domine Constanti, Bataviam Britanniamque squalidum caput silvis et fluctibus exerentem aut te, Maximinae Caesar, Persicos arcus pharetrasque calcantem. nunc enim, nunc demum, iuvat orbem spectare depictum, cum in illo nihil videmus alienum".

$5 \quad$ For other examples (especially Anon. De rebus bellicis) see Traina, "Paesaggio e 'decadenza".

6 Paneg. Lat. 6 (7).8.6; 6 (7) 14.1. On the literary and visual language of Tetrarchic propaganda see Dietrich Boschung and Werner Eck eds. Die Tetrarchie. Ein neues Regierungssystem und seine mediale Präsentation, ZAKMIRA-Schriften 3 (Wiesbaden, 2006). See also 
Similarly, eighteen years before, another panegyrist had described the obligations of the "métier d'Empereur":

To admit into your heart the care of such a great state, and to take upon your shoulders the destiny of the whole world; to forget yourself, to speak, and live for the people; to stand on such a lofty summit of human affairs as to gaze down, as it were, on every land and sea, and to survey in turn with eyes and mind where calm weather is assured, where storms threaten, to observe which governors emulate your justice, which commanders maintain the glory of your courage, to receive countless messengers for every quarter, to send out just as many dispatches, to worry about so many cities and nations and provinces, to spend all one's nights and days in perpetual concern for the safety of all. ${ }^{7}$

This language is typical of Tetrarchic ideology. Although the Augusti and the Caesares run different operational zones, they are at pains to highlight the imperial unity: therefore, the panegyrist of 291 coined the famous formula of $p a t-$ rimonium indivisum which characterizes the Empire of Diocletian and Maximian ("what full or twin brothers share an undivided inheritance so fairly as you share the Roman world?"). ${ }^{8}$ From 305 on, the titulatures of the Tetrarchs insistently recall the universal empire as the orbis: beside usual epithets as $p a-$ cator or restitutor orbis, we also find expressions like orbis terrarum dominus, given to Constantius Chlorus, or even a typical Trajanic formula as propagator orbis terrarum (for Maximinus Daia). And of course, the complex evolution of Constantine's titulature, with a vast range of expressions, and a tacit identification of the imperium Romanum with the orbis terrarium. ${ }^{9}$

Natalia Lozofsky, "Maps and panegyrics: Roman geo-ethnographical rhetoric in Late antiquity and the Middle ages," in Cartography in Antiquity and the Middle Ages. Fresh Perspectives, New Methods, eds. Richard J.A. Talbert and Richard W. Unger (Leiden-Boston, 2008), pp. 169-88.

Paneg. Lat. 10 (2) 13.4: “...admittere in animum tantae rei publicae curam et totius orbis fata suscipere et oblitum quodammodo sui gentibus uiuere et in tam arduo humanarum rerum stare fastigio; ex quo ueluti terras omnes et maria despicias uicissimque oculis ac mente collustres ubi sit certa serenitas; ubi dubia tempestas; qui iustitiam uestram iudices aemulentur, qui uirtutis uestrae gloriam duces seruent, accipere innumerabiles undique nuntios; totidem mandata dimittere, de tot arbibus et nationibus et prouinciis cogitare, noctes omnes diesque perpeti sollicitudine pro omnium salute transigere".

$8 \quad$ Paneg. Lat. 11 (3) 6.3.

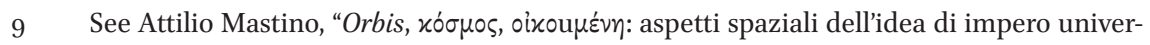
sale da Augusto a Teodosio," in Popoli e spazio romano tra diritto e profezia, Da Roma alla 
Similarly to the Sassanian emperors, who boast that they are the kings of Érān and Anērān, Constantine claims the role of rector of all the nations of the world. ${ }^{10}$ An interesting example is described by Eusebius, who remembers the

... constant diplomatic visitors who brought valuable gifts from their homelands, so that when we ourselves happened to be present we saw before the outer palace gates waiting in a line remarkable figures of barbarians, with their exotic dress, their distinctive apearance, the quite singular cut of hair and beard. The appearance of their hairy faces was foreign and astonishing, their bodily height exceptional. The faces of some were red, of others whiter than snow, of others blacker than ebony or pitch, and others had a mixed colour in between; for men of Blemmyan race, and Indian and Ethiopian, "who are twain-parted last of men" [Hom. Od. 1.23], could be seen of, recounting those mentioned.11

In order to control the oikoumene, the Augustus and his vicars needed not only a survey of the imperial territories, but also of the Barbaricum. After his victories on the Rhine, Constantine struck some coins with the traditional iconography of a defeated kingdom, and with denominations like Alamannia, Francia or Sarmatia: ${ }^{2}$ therefore, imperial propaganda does not present the barbarians as a melting-pot of tribes, but finally accepts their status as federations, deserv-

terza Roma 3 (Naples, 1986), pp. 63-146; Thomas Grünewald, Constantinus Maximus Augustus. Herrschaftspropaganda in der zeitgenössischen Überlieferung (Stuttgart, 1990); Johannes Wienand, Der Kaiser als Sieger. Metamorphosen triumphaler Herrschaft unter Constantin I., Klio. Beiheft Neue Folge 19, Akademie Verlag (Berlin, 2012).

10 On the ideological analogies between the Roman and the Sassanian empires see Matthew Canepa, The two eyes of the Earth: art and rituals of kingship between Rome and Sasanian Iran, The transformation of the classical heritage 45 (Berkeley, 2009). On Constantine as rector see Wienand, Der Kaiser als Sieger, pp. 387-390.

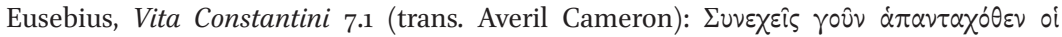

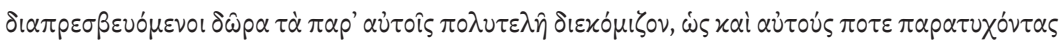

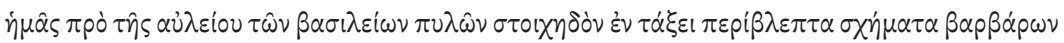

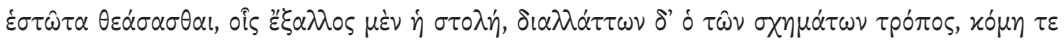

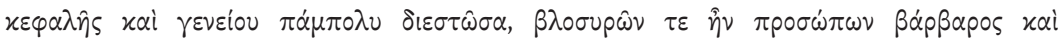

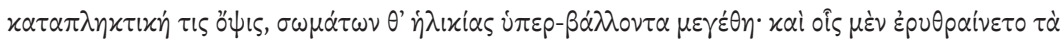

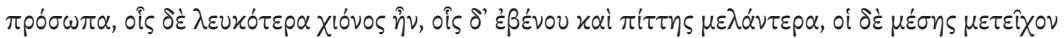

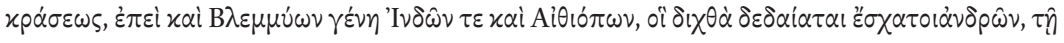

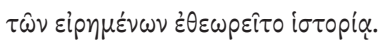

Wienand, Der Kaiser als Sieger, p. 167; 308. 
ing to be considered as states..$^{13}$ Consequently, a good imperial functionary needed at least to acquire a basic knowledge of administrative geography. Exotic, classical names were left to highbrow rhetors, who despised the rough education of scholastici, as we know very well from Libanius. ${ }^{14}$ Some documents coming from the schooldays of imperial functionary can possibly be found in glossaria, laterculi and gazetteers such as the Expositio totius mundiet gentium. Another example may be found in the Verona List, a short but precious text attesting the administrative situation of 314, when the division in dioceses was operational. ${ }^{15}$

Other elements reflect the sensitivity for geography developed during the Tetrarchy. In fact, the division of East and West is a consequence of the agreement of 314 between Constantine and Licinius, after a long struggle for the power. Around 313, Constantine and Licinius are both celebrated as rector orbis terrae in two twin inscriptions of the governor of Sicily. ${ }^{16} \mathrm{~A}$ golden medallion struck in Treviri (between 313 and 315?), with the inscription "to the glory of both Augusti", but with the portrait of Constantine alone, is particularly interesting for the iconography on the reverse. This shows the usual iconography of a walled fortress, or a city, standing beside a body of water; a statue of Victory stands over the gate. Two defeated barbarians are sitting outside the fortress. The barbarian on the left has long hair and a beard, while the other wears a typical Oriental cap (Fig. 3.1).

For a long time, this medallion was interpreted as the first picture of the city of Treviri. ${ }^{17}$ But in my opinion, the mention of both Augusti and the presence of the defeated barbarians give this double solidus a more complex significa-

These coins were distributed as donativa: see Pierre Bastien, Monnaie et donativa au BasEmpire (Wetteren, 1988), p. 76. See also Andreas Goltz, "Franken und Alamannen zur Zeit der Tetrarchie - Überlegungen zu ihrer Ersterwähnung und Ethnogenese zu dem Hintergrund tetrarchischer Herrschaftsstrukturen," in Diokletian und die Tetrarchie. Aspekte einer Zeitenwende, eds. Alexander Demandt, Andreas Goltz and Heinrich SchlangeSchoningen, Millennium-Studien 1 (Berlin-New York, 2004), pp. 95-114. See Marilena Casella, Storie di ordinaria corruzione. Libanio, Orazioni LVI, LVII, XLVI. Introduzione, Traduzione e Commento storico (Messina, 2010), pp. 27-34.

15 Constantin Zuckerman, "Sur la Liste de Vérone et la province de Grande Arménie, la division de l'Empire et la date de création des diocèses," Travaux \& Mémoires 14, Mélanges Gilbert Dagron (2002), pp. 617-637. ILS, $\mathrm{n}^{\circ} 677$; Année épigraphique $1966, \mathrm{n}^{\circ} 166$.

17 RIC Constantine, Treveri 1. Literature in Maria R.-Alföldi, "Das Trierer Stadtbild auf Constantins Goldmultiplum: ein Jahrhundertirrtum," 1991 = Gloria Romanorum. Schriften zur Spätantike, Historia Einzelschriften 153 (Stuttgart, 2001), pp. 143-153. This article tries to show that the fortress represented on the medallion is the castellum Divitia near Cologne. 


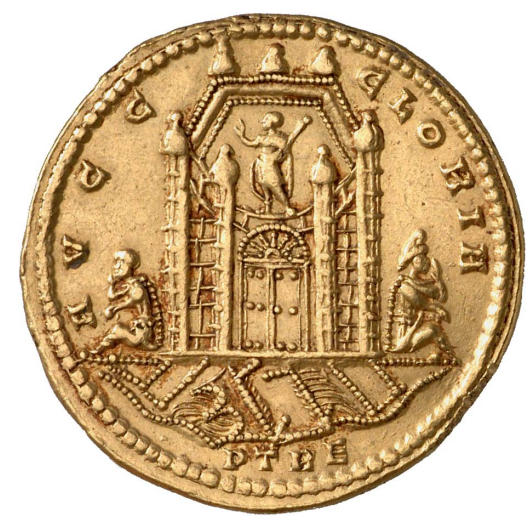

FIGURE 3.1

Reverse of a golden medallion from Treviri. Münzkabinett, Staatliche Museen zu Berlin, 18200450. Pното BY LUTZ-JÜRGEN LÜBKE.

tion. In fact, the fortress represents the Empire as a whole, a stronghold ruling the Mediterranean Sea, well protected by the couple of Augusti, defending the West from the Germans and the East from the Persians. On the other hand, the fortress recalls the only Augustus represented on the medallion, whose main residence was in Treviri. In other words, there is only one Empire, and soon there will be only one Emperor. This is confirmed by an inscription of Surrentum, honoring Constantine as instauratori orbis terrarum perpetuo/ ac piissi$m o$. This division into two partes persists even after Licinius' defeat in 324, and will mark one of the main contradictions of the Late Roman Empire, where the ideological concern of unity does not really match the administrative and juridical reality. The geographical unity is also reflected by Constantine's letter of convocation (only preserved in Syriac) to the Council of Nicaea in 324 . Although most bishops were coming from the East, the "bishop of those outside" (episkopos tōn ektos) insists on the opportunity of the choice of Nicaea in order to allow a good number of Western bishops to participate to the assembly. ${ }^{18}$

Urkunde 20, in Hans-Georg Opitz, Urkunden zur Geschichte der arianischen Streites (Leipzig 1934-1935), pp. 31-42: "I believe it is obvious to everyone that there is nothing more honorable in my sight than the fear of God. Though it was formerly agreed that the synod of bishops should meet at Ancyra in Galatia, it seemed to us for many reasons that it would be well for the synod to assemble at Nicaea, a city of Bithynia, both because the Bishops from Italy and the rest of the countries of Europe are coming, and because of the excellent temperature of the air, and in order that I may be present as a spectator and participator in those things which will be done. Therefore I announce to you, my beloved brothers, that all of you promptly assemble at the said city, that is at Nicaea. Let every one of you therefore, as I said before, keep the greater good in mind and be diligent, without delay in anything, to come speedily, that each may be physically present as a spectator of 
The discovery of a Christian geography was stimulated by the practice of the peregrinatio religiosa.$^{19}$ In the last years of Constantine's reign, an anonymous pilgrim, possibly a high official of the Empire, compiles the Bordeaux Itinerary, which describes the journey he started in the spring of 333, and concluded about one year after - a return trip from Bordeaux to Jerusalem, more than 5,000 Roman miles. At first sight, this text seems an arid gazetteer with no particular theological interest, and definitely less interesting then the Peregrinatio Egeriae, written two generations later. Nonetheless, we find several interesting hints to the historical and religious memory of the places and cities. The pilgrim highlights four metropolises (Milan, Rome, Constantinople and, obviously, Jerusalem), and it is not surprising to notice his limited interest in a glorious city like Antioch, and even in Constantinople. ${ }^{20}$ In fact, for the imagination of a Christian the only possible metropolis is Jerusalem. ${ }^{21}$ But as early as 333, most of the Jewish and Christian lieux de mémoire in Jerusalem were still covered by the structures of Aelia Capitolina. ${ }^{22}$ In a way, the Anonymous pilgrim describes a Jerusalem which is more mental than real:

There are in Jerusalem two large pools (piscinae) at the side of the temple (ad latus templi), that is, one upon the right hand, and one upon the left, which were made by Solomon; and further in the city are twin pools (piscinae gemellares), with five porticoes, which are called Bethsaida [...]. Here is also the corner of an exceeding high tower, where our Lord ascended $[. .$.$] Under the pinnacle of the tower are many rooms, and here$

those things which will be done. God keep you my beloved brothers". On the authenticity of the letter see Richard P.C. Hanson. The Search for the Christian Doctrine of God (Grand Rapids, 1988), pp. 146-151.

19 Pierre Maraval, Lieux Saints et pèlerinages d'Orient (Paris, 1985); Michel-Yves Perrin "Le nouveau style missionnaire: la conquête de l'espace et du temps," in Histoire du Christianisme. 2. Naissance d'une chrétienté (250-430), eds. Jean-Marie Mayeur, Charles Pietri (†), Luce Pietri, André Vauchez and Marc Venard (Paris, 1995), pp. 585-621; Béatrice Caseau, "Sacred Landscapes," in Late Antiquity. A Guide to the Postclassical World, eds. Glen W. Bowersock, Peter Brown, Oleg Grabar (Cambridge, Mass.-London 1999), pp. 21-59; Jan Willem Drijvers, "Helena Augusta, the Cross and the Myth: some new reflections," Millennium 8 (2011), 125-174.

20 Benet Salway, "There but Not There: Constantinople in the Itinerarium Burdigalense," in Two Romes. Rome and Constantinople in Late Antiquity, eds. Lucy Grig and Gavin Kelly (Oxford, 2012), pp. 293-324.

21 John Matthews, "The cultural landscape of the Bordeaux Itinerary," in Roman Perspectives. Studies in the Social, Political and Cultural history of the First to the Fifth Centuries, id. (Swansea, 2010), pp. 181-200.

22 Hagith Sivan, Palestine in Late Antiquity (Oxford, 2008). 
was Solomon's palace. [...] And in the building (in aede) itself, where stood the temple which Solomon built, they say that the blood of Zacharias which was shed upon the stone pavement before the altar remains to this day. There are also to be seen the marks of the nails in the shoes of the soldiers who slew him, throughout the whole enclosure, so plain that you would think they were impressed upon wax. There are two statues of Hadrian, and not far from the statues there is a perforated stone to which the Jews come every year and anoint it, bewail themselves with groans, rend their garments, and so depart. There also is the house of Hezekiah King of Judah. Also as you come out of Jerusalem to go up Mount Sion [...] From thence as you go out of the wall of Sion, as you walk towards the gate of Neapolis, towards the right, below in the valley, are walls, where was the house or praetorium of Pontius Pilate. Here our Lord was tried before His passion. On the left hand is the little hill of Golgotha where the Lord was crucified. About a stone's throw from thence is a vault wherein His body was laid, and rose again on the third day. There, at present, by the command of the Emperor Constantine, has been built a basilica, that is to say, a church (dominicum) of wondrous beauty, having at the side reservoirs (excepturia) from which water is raised, and a bath behind in which infants are washed (baptized). Also as one goes from Jerusalem to the East Gate, in order to ascend the Mount of Olives ...23

23 Itinerary of Bordeaux, 589-594: Sunt in Hierusalem piscinae magnae duae ad latus templi, id est una ad dexteram, alia ad sinistram, quas Salomon fecit, interius uero ciuitati sunt piscinae gemellares quinque porticus habentes, quae appellantur Behtsaida [...] Ibi est anglus turris excelsissimae, ubi dominus ascendit [...] Et sub pinna turris ipsius sunt cubicula plurima, ubi Salomon palatium habebat? [...] Et in aede ipsa, ubi templum fuit, quem Salomon aedificauit, in marmore ante aram sanguinem Zachariae ibi dicas hodie fusum; etiam parent uestigia clauorum militum, qui eum occiderunt, per totam aream, ut putes in cera fixum esse. Sunt ibi et statuae duae Hadriani; est et non longe de statuas lapis pertusus, ad quem ueniunt Iudaei singulis annis et unguent eum et lamentant se cum gemitu et uestimenta sua scindunt et sic recedunt. Est ibi et domus Ezechiae regis Iudae. Item exeuntibus hierusalem, ut ascendas Sion. Est ibi et domus ezechiae regis iudae. Item exeuntibus hierusalem, ut ascendas [...] Inde ut eas foris murum de sion, euntibus ad portam neapolitanam ad partem dextram deorsum in ualle sunt parietes, ubi domus fuit siue praetorium pontii pilati; ibi dominus auditus est, antequam pateretur. A sinistra autem parte est monticulus golgotha, ubi dominus crucifixus est. Inde quasi ad lapidem missum est cripta, ubi corpus eius positum fuit et tertia die resurrexit; ibidem modo iussu Constantini imperatoris basilica facta est, id est dominicum, mirae pulchritudinis habens ad latus excepturia, unde aqua leuatur, et balneum a tergo, ubi infantes lauantur. Item ad hierusalem euntibus ad portam, quae est contra orientem, ut ascendatur in monte Oliueti... 
Should we see in this description, as it has been recently written, a "mechanism of appropriation and expropriation of the Jewish memory and space"?24 True, the Pilgrim makes a selective operation, in order to recover a city which Eusebius considered as a new Jerusalem. ${ }^{25}$ Just to give one example, the "piscina probatica" at Bethesda, where Jesus healed the cripple, is described as a Christian lieu de mémoire (as it was at least from the times of Origen), but in fact was a traditional place of healing for the Jews, and, as the archeological evidence confirms, for the pagans too.

In any case, if the pilgrim of Bordeaux confirms the new identity taken by Jerusalem, he does not accomplish the same operation for Constantinople. The Itinerary mentions a series of civitates, but only one Urbs - Rome, but this is not surprising, as the Pilgrim came from the West, and Constantine's new capital was dedicated only three years before. ${ }^{26}$ In a seminal study on the imperial residences from 284 to 337 , Jean-Pierre Reboul demonstrated that under the Tetrarchy and Constantine, the favorite residences were still Rome, Treviri and Sirmium. ${ }^{27}$ Some years after Constantine's death, Iulius Valerius, the author of a Latin translation of the Romance of Alexander as well as of an Itinerarium Alexandri (and possibly of Trajan too), names the "largest urbes of the oikoumene", according to the circuit of their wall: this time we have Antioch, Carthage, Babylon, Rome and finally Alexandria. ${ }^{28}$ Despite its important circuit of walls, Constantinople is still missing. Delving further into the study of the hierarchy of cities, we may also consider the Calendar of 354, whose Renaissance copies present the iconography of four imperial Tychai: the Western, Urban-centered Philocalus considers here Rome, Carthage, Constantinople and Treviri. ${ }^{29}$ This is again less than surprising, as Roma aeterna, even after the

24 See Oded Irshai, "The Christian Appropriation of Jerusalem in the Fourth Century: The Case of the Bordeaux Pilgrim," Jewish Quarterly Review 99 (2009), 465-486 (476).

25 Eusebius, Life of Constantine 3.33.135.

26 See also Dariusz Brodka, Die Romideologie in der römischen Literatur in der Spätantike (Berlin, 1998).

27 Jean-Pierre Reboul, "L'Ordo urbium nobilium d'Ausone au regard des évolutions de la centralité politique dans l'Antiquité tardive. Approches historique et archéologique," Schedae 8.1 (2007), 107-140. See also Lucy Grig, "Competing Capitals, Competing Representations: Late Antique Cityscapes in Words and Pictures," in Two Romes, pp. 31-52.

28 Jean-Pierre Callu, "Antioche la Grande: la cohérence des chiffres," 1997 = Culture profane et critique des sources de l'Antiquité tardive. Trente et une études de 1974 à 2003 (Rome, 2006), pp. $643-685$.

29 Annette Haug, "Das spätantike Rombild zwischen Visualisierung und Imagination", in Das antike Rom und sein Bild, eds. Hans-Ulrich Cain, Annette Haug, Yadegar Asisi (BerlinNew York, 2011), pp. 69-91. 
sacks of Alaric and of the Vandals in the fifth century, will still keep a major place in the mental map of Late antiquity. ${ }^{30}$ But in Philocalus' mental map (the calendar of 354 presents several texts connected to the topography of the Urbs) Rome is more than one of the four main imperial residences: it is the centre of the Empire, whereas Carthage, Constantinople and Treviri are the strongholds destined to control the three parts of the world, that is, Africa, Asia, and Europe, as well as their frontiers.

Written in the same period, the Expositio totius mundi et gentium (originally composed in Greek) presents a Late antique inventaire du monde, but this time with less consideration for the military aspects, and with a stronger concern for the civil affairs. For example, the abundant riches of the provinces (apart from Greece and Africa) and of the cities are an important point of this text. For this reason, the Expositio has been considered the work of a trader. ${ }^{31}$ More likely, it is the work of an Oriental 'sophist', who wrote a pamphlet destined to teaching, similar to the geographical gazetteer of Vibius Sequester. The same concern for geography can also be detected in the Pseudo-Hegesippus, a fourth-century Latin translator of Josephus' Jewish War who eventually integrated the text with some interesting observations, such as "the Euphrates is Roman": according to Pseudo-Hegesippus this river, which hitherto was inaccessible on both banks, is going to prefigure the next conquest of the East. At the same time Armenia, the faithful ally of the Romans, keeps calm and controls the mountain passes, ready to reject the troubles from external enemies. ${ }^{32}$ This context seems to reflect the geopolitical situation after the battle of Singara in 344, as we can also see from Libanius' Basilikon.

To sum up, the recovery of the Empire after the Tetrarchy favoured the development of new geographies and cosmographies, more or less expressed by their authors' minds. True, it is more difficult to detect the fictional and ideological elements in the literary sources or even in the epigraphic titulatures. And, of course, literary texts may be conservative, leaving a classical appear-

30 Gudrun Bühl, Constantinopolis und Rom: Stadtpersonifikationen der Spätantike (Kilchberg, 1995).

31 Afterwards, scholars pointed at an imperial official, but this is also less than probable, as the text presents some administrative incongruencies, and also thinks that the « Noricum » was a city. See Concetta Molé, "Le tensioni dell'utopia. L'organizzazione dello spazio in alcuni testi tardoantichi," in Le trasformazioni della cultura nella tarda antichità, eds. Mario Mazza and Claudia Giuffrida (Rome, 1985), pp. 691-736.

32 Ps. Heges. 2.9.1. Jean-Pierre Callu, 'Le 'De bello Iudaico' du Pseudo-Hégesippe. Essai de datation," $1987=$ Culture profane, pp. 597-622. The author of this text has been identified with Ambrose of Milan: Chiara Somenzi, Egesippo-Ambrogio: formazione scolastica e cristiana a Roma alla metà del IV secolo (Milan, 2009). 
ance obscuring major structural phenomena: this is the "Pseudomorphose" observed by Spengler and taken into serious consideration by scholars like Eduard Meyer, Henri-Irénée Marrou and Santo Mazzarino. ${ }^{33}$

Of course, political events had a strong influence on these new conceptions and 'Inventaires' of the oikoumene. After all, the Roman Empire was not an imperium sine fine anymore, and the limites were a reality, confirmed by the evolution of the military dispositions between the Tetrarchy and Constantine's reign, and later. ${ }^{34}$ The next step may be observed in the geographical digressions of Ammianus and, more generally, in all texts dealing with the barbarians, now present in every aspect of daily life in Late Antiquity. There was no longer chance to reject the tensions and the anxieties as in the classical past. ${ }^{35}$

\section{Bibliography}

Maria R.-Alföldi, "Das Trierer Stadtbild auf Constantins Goldmultiplum: ein Jahrhundertirrtum," 1991 = Gloria Romanorum. SchriftenzurSpätantike, Historia Einzelschriften 153 (Stuttgart, 2001), pp. 143-153.

Pierre Bastien, Monnaie et donativa au Bas-Empire (Wetteren, 1988).

Dietrich Boschung and Werner Eck eds. Die Tetrarchie. Ein neues Regierungssystem und seine médiale Präsentation, ZAKMIRA-Schriften 3 (Wiesbaden, 2006).

Dariusz Brodka, Die Romideologie in der römischen Literatur in der Spätantike (Berlin, 1998).

Gudrun Bühl, Constantinopolis und Rom: Stadtpersonifikationen der Spätantike (Kilchberg, 1995).

Jean-Pierre Callu, “Le 'De bello Iudaico' du Pseudo-Hégesippe. Essai de datation," 1987 = Culture profane, pp. 597-622.

"Antioche la Grande : la cohérence des chiffres," 1997 = Culture profane et critique des sources de l'Antiquité tardive. Trente et une études de 1974 à 2003 (Rome, 2006), pp. $643-685$.

33 See Hervé Inglebert, Interpretatio Christiana: Les mutations des savoirs (cosmographie, géographie, ethnographie, histoire) dans l'Antiquité chrétienne (30-63o après J.-C.), Collection des Études Augustiniennes 166 (Paris, 2001).

34 Tiberianus, apud Serv. In Verg. Aen. 6.532; see Silvia Mattiacci, I carmi e i frammenti di Tiberiano (Firenze, 1990); Gabriella Moretti, Gli Antipodi. Avventure letterarie di un mito scientifico (Parma, 1994), p. 46.

35 Fabrizio Feraco, Ammiano geografo. La digressione sulla Persia (Naples, 2004); Ammiano geografo. Nuovi studi (Naples, 2011); Wiebke Vergin, Das Imperium Romanum und seine Gegenwelten. Die geographisch-ethnographische Exkurse in den 'Res Gestae' des Ammianus Marcellinus (Berlin-Boston, 2013). 
Averil Cameron, "Democratization Revisited: Culture and Late Antique and Early Byzantine Elites," in The Byzantine and Early Islamic Near East. Elites Old and New, eds. John Haldon, Lawrence I. Conrad, Studies in Late Antiquity and Early Islam 1.vi (Princeton, 2004), pp. 91-108.

Matthew Canepa, The two eyes of the Earth: art and rituals of kingship between Rome and Sasanian Iran, The transformation of the classical heritage 45 (Berkeley, 2009).

Michel Carrié, "Antiquité tardive et 'démocratisation de la culture'. Un paradigme à géométrie variable," Antiquité tardive 9 (2001), 27-46.

Béatrice Caseau, "Sacred Landscapes," in Late Antiquity. A Guide to the Postclassical World, eds. Glen W. Bowersock, Peter Brown, Oleg Grabar (Cambridge, Mass.-London 1999), pp. 21-59.

Marilena Casella, Storie di ordinaria corruzione. Libanio, Orazioni LVI, LVII, XLVI. Introduzione, Traduzione e Commento storico (Messina, 2010).

Jan Willem Drijvers, "Helena Augusta, the Cross and the Myth: some new reflections," Millennium 8 (2011), 125-174.

Andreas Goltz, "Franken und Alamannen zur Zeit der Tetrarchie - Überlegungen zu ihrer Ersterwähnung und Ethnogenese zu dem Hintergrund tetrarchischer Herrschaftsstrukturen," in Diokletian und die Tetrarchie. Aspekte einer Zeitenwende, eds. Alexander Demandt, Andreas Goltz and Heinrich Schlange-Schoningen, Millennium-Studien 1 (Berlin-New York, 2004), pp. 95-114.

Fabrizio Feraco, Ammiano geografo. La digressione sulla Persia (Naples, 2004). , Ammiano geografo. Nuovi studi (Naples, 2011).

Lucy Grig, "Competing Capitals, Competing Representations: Late Antique Cityscapes in Words and Pictures," in Two Romes. Rome and Constantinople in Late Antiquity, eds. Lucy Grig and Gavin Kelly (Oxford, 2012), pp. 31-52.

Thomas Grünewald, Constantinus Maximus Augustus. Herrschaftspropaganda in der zeitgenössischen Überlieferung (Stuttgart, 1990).

Richard P.C. Hanson. The Search for the Christian Doctrine of God (Grand Rapids, 1988). Annette Haug, "Das spätantike Rombild zwischen Visualisierung und Imagination", in Das antike Rom und sein Bild, eds. Hans-Ulrich Cain, Annette Haug, Yadegar Asisi (Berlin-New York, 2011), pp. 69-91.

Antony Hostein, La cité et l'Empereur. Les Éduens dans l'Empire romain d'après les Panégyriques latins (Paris, 2012), pp. 177-250.

Mark Humphries, "A New Created World: classical geographical texts and Christian contexts in late antiquity," in Texts and Culture in Late Antiquity: inheritance, authority, and change, ed. J.H. David Scourfield (Swansea, 2007), pp. 33-67.

Hervé Inglebert, Interpretatio Christiana:Les mutations des savoirs (cosmographie, géographie, ethnographie, histoire) dans l'Antiquité chrétienne (30-63o après J.-C.), Collection des Études Augustiniennes 166 (Paris, 2001). 
Oded Irshai, "The Christian Appropriation of Jerusalem in the Fourth Century: The Case of the Bordeaux Pilgrim," Jewish Quarterly Review 99 (2009), 465-486 (476).

Giuseppe La Bua, "Patronage and education in third-century Gaul:Eumenius' Panegyric for the Restoration of the Schools," Journal of Late Antiquity 3 (2010), 300-315.

Natalia Lozofsky, "Maps and panegyrics: Roman geo-ethnographical rhetoric in Late antiquity and the Middle ages," in Cartography in Antiquity and the Middle Ages. Fresh Perspectives, New Methods, eds. Richard J. A. Talbert and Richard W. Unger (LeidenBoston, 2008), pp. 169-88.

Pierre Maraval, Lieux Saints et pèlerinages d'Orient (Paris, 1985).

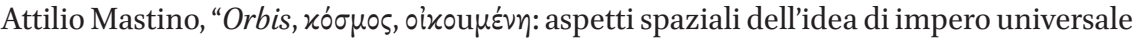
da Augusto a Teodosio," in Popoli e spazio romano tra diritto e profezia, Da Roma alla terza Roma 3 (Naples, 1986), pp. 63-146.

John Matthews, "The cultural landscape of the Bordeaux Itinerary," in Roman Perspectives. Studies in the Social, Political and Cultural history of the First to the Fifth Centuries, id. (Swansea, 2010), pp. 181-200.

Silvia Mattiacci, I carmi e i frammenti di Tiberiano (Firenze, 1990).

Concetta Molé, "Le tensioni dell'utopia. L'organizzazione dello spazio in alcuni testi tardoantichi," in Le trasformazioni della cultura nella tarda antichità, eds. Mario Mazza and Claudia Giuffrida (Rome, 1985), pp. 691-736.

Gabriella Moretti, Gli Antipodi. Avventure letterarie di un mito scientifico (Parma, 1994). Hans-Georg Opitz, Urkunden zur Geschichte der arianischen Streites (Leipzig 19341935).

Michel-Yves Perrin “Le nouveau style missionnaire: la conquête de l'espace et du temps," in Histoire du Christianisme. 2. Naissance d'une chrétienté (250-430), eds. Jean-Marie Mayeur, Charles Pietri (†), Luce Pietri, André Vauchez and Marc Venard (Paris, 1995), pp. 585-621.

Jean-Pierre Reboul, "L'Ordo urbium nobilium d'Ausone au regard des évolutions de la centralité politique dans l'Antiquité tardive. Approches historique et archéologique," Schedae 8.1 (2007), 107-140.

Benet Salway, "There but Not There: Constantinople in the Itinerarium Burdigalense," in Two Romes. Rome and Constantinople in Late Antiquity, eds. Lucy Grig and Gavin Kelly (Oxford, 2012), pp. 293-324.

Hagith Sivan, Palestine in Late Antiquity (Oxford, 2008).

Chiara Somenzi, Egesippo-Ambrogio:formazione scolastica e cristiana a Roma alla metà del IV secolo (Milan, 2009).

Giusto Traina, "Paesaggio e 'decadenza'. La palude nella trasformazione del mondo antico," in Società romana e impero tardoantico, 3: le mercigli insediamenti, ed. Andrea Giardina (Rome-Bari, 1986), pp. 711-730; 905-917.

"Luoghi della transizione. Appunti sul paesaggio antico," Compar(a)ison 2 (1998), 79-91. 
—_, "Geografia dell'impero," in Enciclopedia costantiniana. Sulla figura e l'immagine dell'imperatore del cosiddetto Editto di Milano. 313-2013, eds. Alberto Melloni, Mara Dissegna and Davide Dainese, 1 (Rome, 2013), pp. 583-598.

_ , "Mapping the World under Theodosius II," in Theodosius II and the making of late antiquity, ed. Christopher Kelly (Cambridge, Eng., 2013), pp. 115-171.

Wiebke Vergin, Das Imperium Romanum und seine Gegenwelten. Die geographisch-ethnographische Exkurse in den 'Res Gestae' des Ammianus Marcellinus (Berlin-Boston, 2013).

Johannes Wienand, Der Kaiser als Sieger. Metamorphosen triumphaler Herrschaft unter Constantin I., Klio. Beiheft Neue Folge 19, Akademie Verlag (Berlin, 2012).

Constantin Zuckerman, "Sur la Liste de Vérone et la province de Grande Arménie, la division de l'Empire et la date de création des diocèses," Travaux \& Mémoires 14, Mélanges Gilbert Dagron (2002), 617-637. 